\title{
ハイブリッドシステムの非線形現象
}

\section{Nonlinear Phenomena in Hybrid Systems}

\author{
潮 俊光 Toshimitsu USHIO \\ 金澤尚史 Takafumi KANAZAWA
}

\section{1. まえがき}

連続変数 (実数值変数) と離散変数 (シンボル変数, 整数值 変数) の両方が共存するシステムを一般にハイブリッドダイ ナミカルシステムまたは, 単にハイブリッドシステムという (1). ハイブリッドシステムの典型的な例としてスイッチング 回路がある ${ }^{(2),(3)}$. スイッチング素子はオンとオフの 2 值を 取る離散変数で記述されるので, スイッチング素子を含む回 路ではその 2 值に依存して回路を記述する微分方程式が異な り, その次元も変化する。 ハイブリッドシステムでは, 離散 変数の振舞いは区分的定数で, 離散変数が变化するときに連 続変数が滑らかではなくなったりジャンプすることもある. そのため, ハイブリッドシステムの解析はかなり難しく, 現 在でも多くの未解決問題がある.

「ハイブリッドシステム」という言葉が学術論文で用いられ たのは1960年代までさかのぼることができる(4).また， 1950 年代から研究されている切換制御やリレ一回路などもハイブ リッドシステムであり，その意味では，八イブリッドシステ ムは古くて新しい研究テーマと言うべきかもしれない。しか し, 現在の研究が $1950 ６ 0$ 年代の研究と大きく異なる点は, 離散変数のダイナミクスを陽に取り込んだモデルの出現と計 算機科学と非線形システム理論・非線形科学の交流が挙げら れる. 最近では, ハイブリッドシステムの応用が工学にとど まらず，様々な分野に広がりつつある。例えば，ゲノムの機 能発現モデル (6), (7), 生命現象のモデル ${ }^{(8),(9)}$, 経済学 ${ }^{(10)}$ など がある。

ハイブリッドシステムを対象にしたワークショップが 1990 年代に計算機科学のグループを中心に, 非線形力学系, 非線 形システム理論などの研究者も参加して, 毎年開催されるよ うになり，その論文集がLecture Notes in Computer Scienceか ら出版されている。 今でも,「Hybrid Systems: Computation and Control (HSCC)」が毎年3月下旬か 4 月上旬に開催されてい

潮 俊光 正員 大阪大学大学院基礎工学研究科システム創成専攻 E-mail ushio@sys.es.osaka-u.ac.jp

金澤尚史正員 大阪大学大学院基礎工学研究科システム創成専攻

E-mail_kanazawa@sys.es.osaka-u.ac.jp

Toshimitsu USHIO, Member (Graduate School of engineering Science, Osaka University, Toyonaka-shi, 560-8531 Japan), Takafumi KANAZAWA, Member (Graduate School of engineering Science, Osaka University, Toyonaka-shi, 560-8531 Japan)

Fundamentals Review Vol.1 No.1 pp.41-50 2007年7月
る.また, IFAC (International Federation on Automatic Control) が主催で「Analysis and Design of Hybrid Systems (ADHS)」が 3 年ごとに開催されている. また, 多くの学術雑誌においても ハイブリッドシステムの特集号が企画されている。詳細は文 献（11）を参照されたい.

本稿では, ハイブリッドシステムの非線形現象に関する幾 つかの話題を紹介する。 まず2. では, ハイブリッドシステ ムのモデルとして最もよく使われるハイブリッドオートマト ンを紹介する. 3. では, 区分的に滑らかなシステムにおけ る Filippov解を定義し, スライディングモードについて説明 する. 4. では, 微分不可能性に起因する分岐現象について 説明する. 5. では, カオスの存在するハイブリッドシステ ムとして有名なスイッチトアライバルシステムに対するカオ ス制御について述べる. 6. は八イブリッドレプリケータダ イナミックスについて紹介する.

\section{2. ハイブリッドオートマトンモデル}

従来から連続変数のダイナミックスは微分方程式で, 離散 変数のダイナミックスはオートマトンやペトリネットなどで 記述される。これらのモデルを組み合わせることでハイブ リッドシステムをモデル化する。本章では, ハイブリッドシ ステムのモデル表現として最も標準的で一般性のあるハイブ リッドオートマトンモデルを紹介する.

従来のオートマトンは離散状態と事象の生起による状態遷 移の関係を表し, 罒的表現として, グラフが用いられる。一 般に離散状態を節点に, 遷移を事象でラベル付けされた枝で 表す. 各節点に連続変数の時間発展の記述を加えたものをハ イブリッドオートマトンという。 ハイブリッドオートマトン は離散状態の遷移が図的に理解しやすいという利点がある. ハイブリッドオートマトンは次の要素からなる ${ }^{(12),(13) .}$

\section{- 変数}

実数值を取る状態 (連続状態)を表すための変数の集合, $x$ : $=\left[x_{1}, x_{2}, \ldots, x_{n}\right]$, 連続状態の微分值を表す変数の集合 $\dot{x}:$ $=\left[\dot{x}_{1}, \dot{x}_{2}, \ldots, \dot{x}_{n}\right]$, 並びに離散状態の変化による連続 状態の変化を表す変数の集合 $x^{\prime}:=\left[x_{1}^{\prime}, x_{2}^{\prime}, \ldots, x_{n}^{\prime}\right]$ 用いる。ただし, $n$ は連続状態の次元である. 


\section{・制御グラフ}

離散変数間の遷移を表すために, 有向多重グラフ $(V, E)$ を用いる。ただし, 集合 $V$ は節点集合で, 各節点が離散 状態を表す。 $E$ は枝集合で, 各枝は離散状態間の遷移関 係を表す。

\section{・ ラベリング関数}

各離散状態 $v \in V$ に対して集合init, inv, flowがある. init $(v) \subseteq \Re^{n}$ は $v$ から始まる軌道の取り得る初期条件の集合 を, inv $(v) \subseteq \Re^{n}$ は離散状態 $v て ゙ x$ が取り得る值の集合を， flow $(v) \subseteq \Re^{n} \times \Re^{n}$ は $v$ での連続変数の (連続的) 変化を表 す $(x, \dot{x})$ の取り得る值の集合を，それぞれ表している。

\section{・ ジャンプ条件}

各枝 $e \in E$ に対して, 離散状態の遷移前後での連続状態 の変化を表すために, $x \cup x^{\prime}$ が取り得る值の集合jump $(e)$ $\subseteq \Re^{n} \times \Re^{n}$ を用いる.

\section{- 事象}

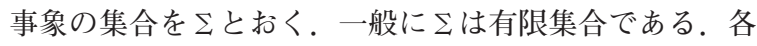
枝と事象の関係を表す関数を event $: E \rightarrow \Sigma$ とおく. すなわち, 各枝 $e \in E$ に対して, event $(e) \in \Sigma$ ¿その遷 移のときに生起する事象を表す.

ハイブリッドオートマトンによるモデル化の例は5. と6. で述べる。

\section{3. 区分的に滑らかな微分方程式モデル}

連続変数のダイナミックスに注目したモデルとして，次式 で書ける区分的に滑らかな常微分方程式モデルがある.

$$
\dot{x}(t)=f(x(t), \mu)= \begin{cases}f_{-}(x(t), \mu) & \text { if } H(x(t)) \leq 0 \\ f_{+}(x(t), \mu) & \text { if } H(x(t))>0\end{cases}
$$

ただし,$x(t) \in \Re^{n}$ は状態, $\mu \in \Re$ はパラメータ, $f_{-}: \Re^{n} \times$ $\Re \rightarrow \Re^{n}$ と $f_{+}: \Re^{n} \times \Re \rightarrow \Re^{n}, H: \Re^{n} \rightarrow \Re$ は十分に滑らかな関数 である. $H(x)=0$ によって定義される $(n-1)$ 次元の滑ら かな多様体 $S$ にって $\Re^{n}$ は領域 $S_{-}=\left\{x \in \Re^{n}: H(x)<0\right\}$ と $S_{+}=\left\{x \in \Re^{n}: H(x)>0\right\}$ に分割される. 多様体 $S$ はジャン プ条件に相当し, 軌道が $S$ 上を通過するときに離散状態が $S$ から $S_{+}$または $S_{+}$から $S_{-}$に遷移することになる。

境界 $S$ 上で $f$ が不連続である場合には, 式 (1)の解の概念 を拡張する必要がある。その中で有名な拡張にFilippovの意 味での解という概念がある ${ }^{(14)}$. 解がジャンプする場合にはこ の概念が適用できないが，連続となる場合には有効な概念で ある。式 (1) に対して次の微分包含を考える.

$$
\begin{aligned}
& \dot{x}(t) \in F(x(t), \mu)= \\
& \begin{cases}f_{-}(x(t), \mu) & \text { if } H(x(t))<0 \\
\overline{c o}\left\{f_{-}(x(t), \mu), f_{+}(x(t), \mu)\right\} & \text { if } H(x(t))=0 \\
f_{+}(x(t), \mu) & \text { if } H(x(t))>0\end{cases}
\end{aligned}
$$

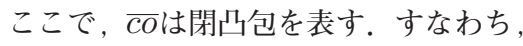

$\overline{c o}\left\{f_{-}, f_{+}\right\}=\left\{(1-q) f_{-}+q f_{+}: q \in[0,1]\right\}$

である。式 (1) から式 (2)に拡張することはFilippovの凸手法 と言われる。

絶対連続な関数 $x:[0, \tau] \rightarrow \Re^{n}$ が, ほとんどすべての $t \in$ $[0, \tau]$ で式 $(2)$ を満たすとき, $x(t)$ を Filippovの意味での式 (1) の解という. 各 $x$ で集合 $F(x, \mu)$ が閉, 凸, 及び有界で あり,更に $F(\cdot, \mu)$ が上半連続ならば,絶対連続な関数 $x:[0, \tau]$ $\rightarrow \Re^{n}$ が式 (2) の解となるような $\tau>0$ が存在する ${ }^{(15)}$.ここで, 次式を満たすとき, $F(\cdot, \mu)$ は点 $x \in \Re^{n}$ で上半連続であると いう.

$$
\lim _{y \rightarrow x}\left(\sup _{a \in F(y, \mu)} \inf _{b \in F(x, \mu)}\|a-b\|\right)=0 \quad \forall x \in \Re^{n}
$$

このように, 式 (2) に拡張した後で境界 $S$ を横切る解を定義 できるようになる.

ここで, 境界上の点 $x \in S$ での境界の法線べクトルは $\nabla H$ $(x)$ である。 また二つのべクトル $a$ と $b$ の内積を $\langle a, b\rangle$ と書 くことにする. 図1に示すように, Filippov解は境界付近で以 下の三つに分類することができる.

- $\left\langle\nabla H(x), f_{-}(x, \mu)\right\rangle\left\langle\nabla H(x), f_{+}(x, \mu)\right\rangle>0$ のとき は図 1 (a) に示すように解は境界を横断的に横切って通過 する。

- $\left\langle\nabla H(x), f_{-}(x, \mu)\right\rangle>0,\left\langle\nabla H(x), f_{+}(x, \mu)\right\rangle<0$ のときは図 $1(\mathrm{~b})$ に示すように,$S_{-}$及び $S_{+}$から出発する 解は境界 $S$ に向かって進み, 境界と衝突すると, 境界上 を動く解となる。この境界上を動く軌道のことをスライ ディングモードと呼ぶ。この場合には安定なスライディ ングモードが存在する. 制御工学では, 制御入力を切り 換えることにより切換面に沿って軌道を平衡点に収束さ せるスライディングモード制御と呼ばれる方法が古くか ら知られている ${ }^{(17)}$ 。スライディングモードは境界上を動 くので, 対応するべクトル $f$ は $\langle\nabla H(x), f(x, \mu)\rangle=0$ を満たす。このことから

$f(x, \mu)=(1-q) f_{-}(x, \mu)+q f_{+}(x, \mu)$

となる，ただし 


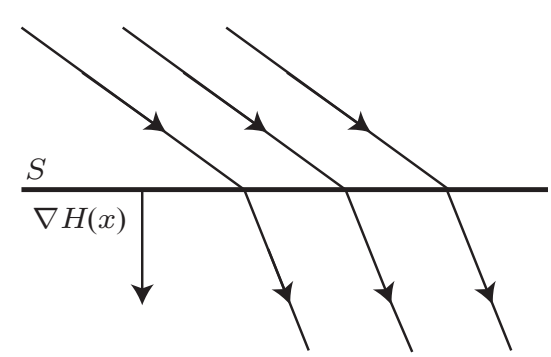

(a) 境界と横断的に通過する軌道の例

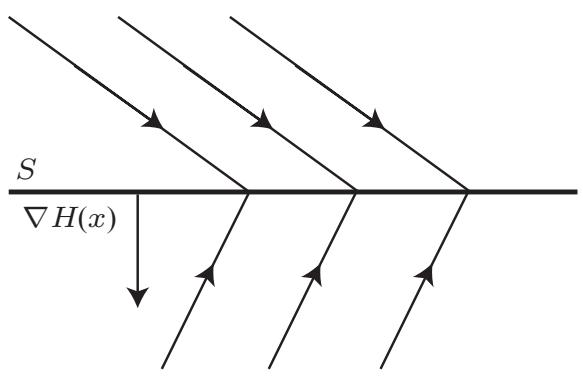

(b) 安定なスライディングモードの例

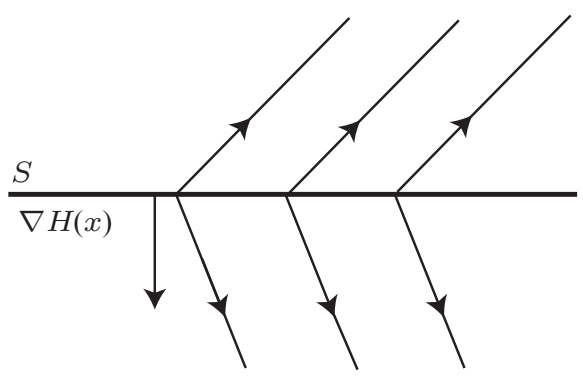

(c) 不安定なスライディングモードの例

図1 区分的に滑らかなシステムのFilippovの意味での解の例

$$
q=\frac{\left\langle\nabla H(x), f_{-}(x, \mu)\right\rangle}{\left\langle\nabla H(x), f_{-}(x, \mu)-f_{+}(x, \mu)\right\rangle}
$$

である。

- $\left\langle\nabla H(x), f_{-}(x, \mu)\right\rangle<0,\left\langle\nabla H(x), f_{+}(x, \mu)\right\rangle>0$ のときは図 1 (c) に示すように, スライディングモードが 存在するが, 境界上の解は不安定であり, 実システムで は対応する解は観測されない.

式（1）の平衡点を $\bar{x}_{\mu}$ とおく. $\bar{x}_{\mu}$ がジャンプ条件 $S$ 上になけ ればヤコビ行列 $J\left(\bar{x}_{\mu}, \mu\right)$ は定義できる.

$$
J(x, \mu)= \begin{cases}J_{-}(x, \mu)=D_{x} f_{-}(x, \mu) & \text { if } x \in S_{-} \\ J_{+}(x, \mu)=D_{x} f_{+}(x, \mu) & \text { if } x \in S_{+}\end{cases}
$$

$\bar{x}_{\mu} \in S$ ときの (集合值)一般化ヤコビ行列を以下のように 定義する.

$$
J(x, \mu)=\left\{J_{q}(x, \mu): q \in[0,1]\right\}
$$

ただし，

$$
J_{q}(x, \mu)=(1-q) J_{-}(x, \mu)+q J_{+}(x, \mu)
$$

である.すなわち， $S$ 上での一般化ヤコビ行列 $J(x, \mu)$ とは $J_{-}(x, \mu)$ と $J_{+}(x, \mu)$ の閉凸包である. $J(x, \mu)$ の固有值 は集合 $\left\{\left(\lambda_{q, 1}, \ldots, \lambda_{q, n}\right): \operatorname{det}\left(\lambda_{q, i} I-J_{q}\right)=0, i \in\{1,2, \ldots, n\}\right.$, $q \in[0,1]\}$ となる.

\section{4. ハイブリッドシステムの分岐䫖}

滑らかな微分方程式での分岐現象の研究に比べると, 八イ ブリッドシステムの分岐現象は十分に解明されていない。 八 イブリッドシステム特有の分岐現象は, ベクトル場が滑らか でないことに起因する。

\section{1 平衡点の分岐}

平衡点が境界 $S$ を横切るときに局所分岐が発生することが ある.このとき, 平衡点周りの線形化システムのヤコビ行列 が境界上では存在せず，その前後で固有值が不連続となるの で，このような分岐は不連続分岐と呼ばれることがある ${ }^{(15)}$. 不連続分岐は一般化ヤコビ行列を用いて解析することができ る.滑らかなシステムの場合と同様にサドル・ノード分岐, トランスクリティカル分岐, ピッチフォーク分岐が発生し得 る．滑らかなシステムの場合にはこれらの分岐は平衡点での ヤコビ行列の固有值に 0 が存在したときに発生する。 区分的

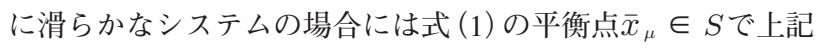
のいずれかの分岐が発生するならば

$$
\exists q \in[0,1]: \operatorname{det} J_{q}\left(\bar{x}_{\mu}, \mu\right)=0
$$

が成り立つ。つまり, 式 (5) は上記の分岐が発生するための 必要条件となる。例えば，次のシステムを考える。

$$
\dot{x}=f(x, \mu)=\mu-|x|
$$

$\mu=0$ のとき, 平衡点は $x=0$ となり, その点での一般化ヤ コビ行列は

$$
J(0,0)=\left\{J_{q}=-2 q+1: q \in[0,1]\right\}=[-1,1]
$$

となるので, $q=1 / 2$ と打けば，固有值 0 を持つことになる. このシステムでは図2 (a) のようにサドル・ノード分岐が発 生する。これは滑らかなシステム

$$
\dot{x}=\mu-x^{2}
$$

とよく似た分岐である。同様にトランスクリティカル分岐と ピッチフォーク分岐の例を図2 (b)，(c) に示す. 
次に以下の二次元システムを考える.

$$
\begin{aligned}
& \dot{x}_{1}=x_{2} \\
& \dot{x}_{2}=-x_{2}-2\left|x_{2}-\mu\right|-x_{1}
\end{aligned}
$$

式 (7) の平衡点は

$$
x_{1}=-2|\mu|, \quad x_{2}=0
$$

であり, $\mu=0$ のとき平衡点でシステムは微分不可能となり， Hopf 分岐が発生する。このときの一般化ヤコビ行列は $J(0$, $0)=\left\{J_{q}: q \in[0,1]\right\}$ である。ただし，

$$
\begin{aligned}
J_{q} & =q\left[\begin{array}{cc}
0 & 1 \\
-1 & 1
\end{array}\right]+(1-q)\left[\begin{array}{cc}
0 & 1 \\
-1 & -3
\end{array}\right] \\
& =\left[\begin{array}{cc}
0 & 1 \\
-1 & -3+q
\end{array}\right]
\end{aligned}
$$

$q=3 / 4$ のとき, $J_{3 / 4}$ の固有值は土 $j$ となる.

このように, $\mu=\mu_{b}$ で平衡点 $\bar{x}$ が Hopf 分岐するとき, $q$ を 0 から 1 まで動かしたときの $J_{q}\left(\bar{x}, \mu_{b}\right)$ の固有值の軌跡を複 素平面上に描くと, 純虚数で虚軸を横切る。しかし, 一般に その逆は言えない，また，固有值が虚軸と複数回交差する場 合には複雑な分岐が発生し得る. 例えば, サドル点, 不安定 フォーカス, 及び安定周期軌道が同時に消滅 (または発生)す るようなこともある。詳細は文献 (15), (16) を参照されたい.

\section{2 周期軌道の分岐}

図3に示すようにパラメータ $\mu$ が変化し,$\mu=\mu_{b}$ で周期軌 道が境界 $S$ と接したとき, その前後で分岐が観測される。文 献（19）によれば, 分岐が発生して, 軌道が境界 $S$ を滑らか ではないが連続的に変化する場合に $C$-分岐またはbordercollision 分岐と呼び, 軌道が不連続に変化するとき grazing 分 岐と分類されている。 $C$-分岐は 1970 年代にロシアの Feigin によって研究されており ${ }^{(20)} \sim(22)$, border-collision分岐は離散 時間システムにおいて周期点が境界と衝突することで発生す る分岐としてNusseらによって研究された ${ }^{(23) ，(24) . ち な み に, ~}$ Cはロシア語の shivanije (「縫う」という意味)に由来してい る. grazing 分岐は主に衝突のある機械システムに扣いて研究 されており, パラメータの変動によって衝突が発生すること でリミットサイクルが不安定化してカオス的軌道が発生する ことが報告されている ${ }^{(25),(26)}$.これらの分岐は, 当初は全く 独立に研究されてきた。しかし, その発生メカニズムはよく 似ている ${ }^{(27)}$. 本稿では, 周期軌道が境界と接することで発生 する分岐を総称して grazing 分岐と呼ぶことにする.

領域 $S_{\mathrm{i}}(i=-,+)$ でのべクトル場が境界 $S$ と接する $x$ の 集合を $G_{i}$ とおく.つまり,

$$
G_{i}=\left\{s \in S:\left\langle\nabla H(x), f_{i}(x)\right\rangle=0\right\} \quad i=-,+(8)
$$

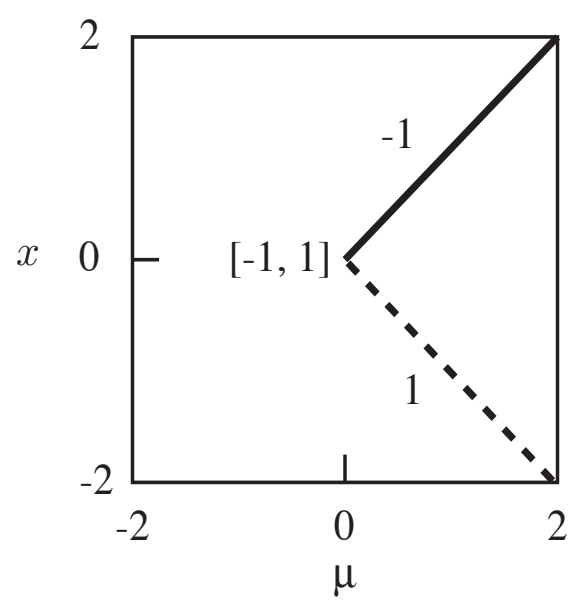

(a) サドル・ノード分岐の例 $(\dot{x}=\mu-|x|$ の分岐図 $)$

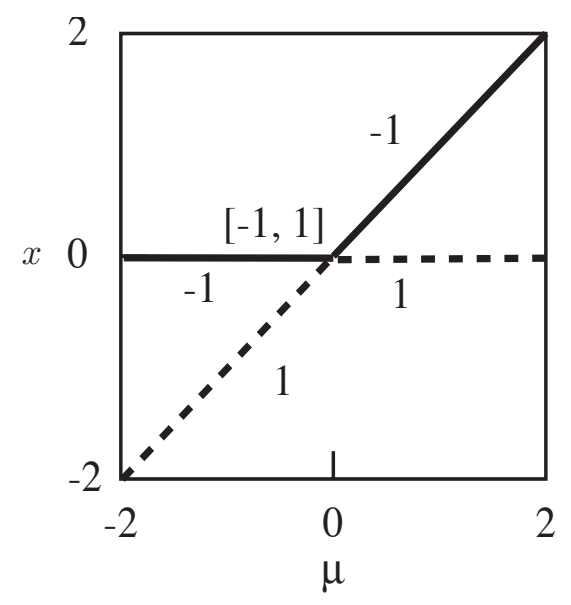

(b) トランスクリティカル分岐の例 $\left(\dot{x}=\left|\frac{1}{2} \mu\right|-\left|x-\frac{1}{2} \mu\right|\right.$ の分岐図 $)$

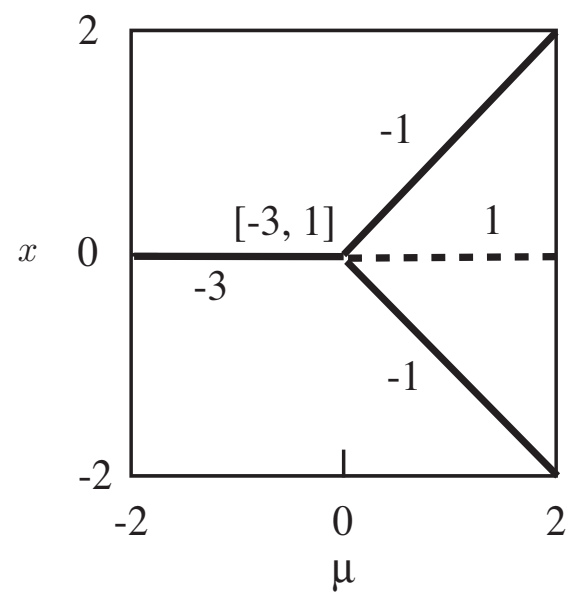

(c) ピッチフォーク分岐の例

$\left(\dot{x}=-x+\left|x+\frac{1}{2} \mu\right|-\left|x-\frac{1}{2} \mu\right|\right.$ の分岐図 $)$

図2 区分的に滑らかなシステムの平衡点の分岐図実線は安定 な平衡点, 点線は不安定な平衡点を表し, 線上の数字もしくは区 間はその (一般化) 固有值である。いずれの分岐に扎いても分岐点 での一般化固有值に 0 が含まれている. 


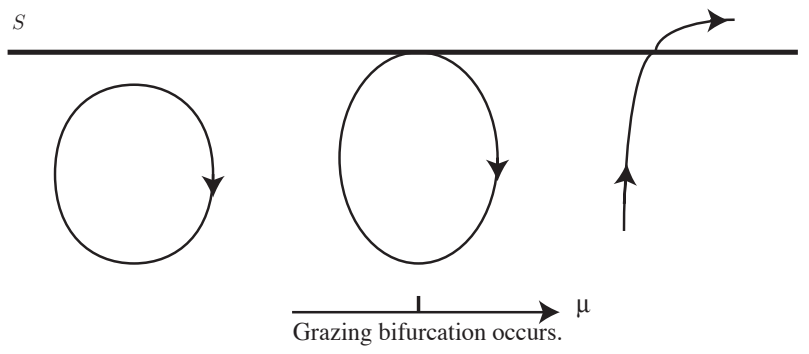

図3 grazing 分岐の概念図 パラメータが変化することで, 周 期軌道が境界 $S$ と衝突することで解が急激に変化する.

もし $G_{i} \neq G_{2}$ ならば，図1に示すようにスライディングモー ドと呼ばれる境界 $S$ 上を動く解が存在する。ここでは，スラ イディングモードが発生しないシステムを対象に説明する. 以下, $G_{i}=G_{2}$ と打く. スライディングモードが発生する分 岐は sliding 分岐とも呼ばれ, 詳細は文献 (18) を参照されたい.

周期 $T$ の周期軌道 $\Phi(t)$ が点 $\bar{x} に$ おいて境界 $S$ と接したとす る。一般性を失うことなく $\Phi(0)=\bar{x}$ と扎いてよい。 このと き以下の式が成り立つならば grazing 分岐が発生する ${ }^{(27)}$.

$$
\begin{aligned}
\Phi(0) & =\Phi(T)=\bar{x} \in G_{i} \\
\Phi(t) & =f(\Phi(t), \mu) \\
\nabla H(\bar{x}) & \neq 0 \\
\left\langle\nabla H(\bar{x}), f_{i}(\bar{x} \mu)\right\rangle & =0 \\
\left.\frac{\mathrm{d}^{2} H(\Phi(\bar{x}, t))}{\mathrm{d} t^{2}}\right|_{t=0}=\left\langle\nabla H(\bar{x}), \frac{\partial f_{i}(\bar{x})}{\partial x} f_{i}(\bar{x})\right\rangle & \\
& +\left\langle\frac{\partial^{2} H(\bar{x})}{\partial x^{2}} f_{i}(\bar{x}), f_{i}(\bar{x})\right\rangle>0
\end{aligned}
$$

ここで, 式 (9) と式 (10) は周期軌道 $\Phi$ が境界 $S$ 上の点 $\bar{x} を$ 通る式 (1) の解であること, 式 (11) は点 $\bar{x} て ゙$ 境界 $S$ は特異に なっていないこと, 式 (12) は周期軌道が境界と接しているこ と, そして式 (13) は $S_{-}$と $S_{+}$での軌道の曲率の符号が同じで あることを表しており，ここでは，それが正であると仮定し ている.

Donde と Hiskenはシューティング法を用いて grazing 分岐 集合を求める方法を提案し，2 足歩行ロボットに応用してい る ${ }^{(28),(29)}$. Maらは非自律システムの場合も含めた計算方法 を提案している ${ }^{(30)}$. しかし, 多くの研究では, ポアンカレ 写像を用いて離散時間システムを求め，離散時間システ ムの border-collision分岐として扱うことが多い(31)，(3). また， 二次元離散時間システムでは, border-collision分岐に関する ノーマルフォームが求められている(23). 最近では, 分岐の 前後では漸近安定であるが境界上にあるときのみ不安定とな る dangerous border-collision分岐という現象が報告されている (32), (33). 多くの研究は余次元 1 の分岐を対象にしていたが, 余次元 2 の分岐の研究も始まっている ${ }^{(34)}$.

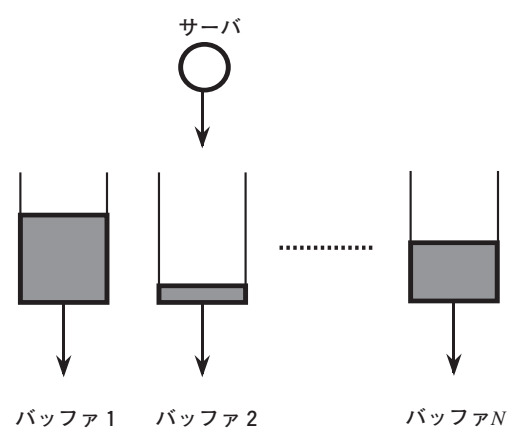

(a) スイッチトアライバルシステム

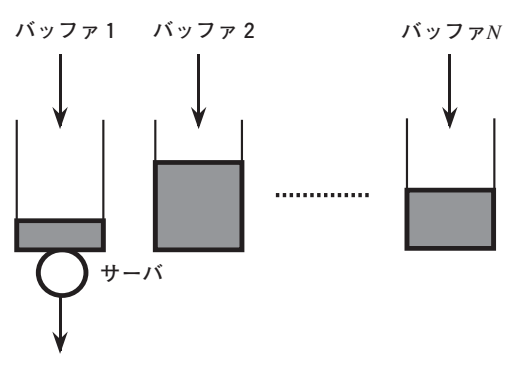

(b) スイッチトサーバシステム

図4 スイッチトフローシステム

\section{5. スイッチトフローシステムのカオス}

\section{1 スイッチトフローシステム}

スイッチトフローシステムはバッファとサーバからなるシ ステムで, 四 4 に示すようにスイッチトアライバルシステム (SAS) とスイッチトサーバシステム (SSS) に分類することが できる. SAS はN個のバッファが一定の速度でパーッを処 理し， 1 台のサーバが $N$ 個のバッファの中の一つにパーツ を供給するシステムである。ここで, 供給されるパーツの量 とバッファで処理されるパーッの総計は等しいと仮定してお く.サーバのスケジューリングとして, 空になったバッファ にサーバを切り換えるという単純な規則を用いると, システ ムの振舞いはカオス的となり，N=3のときにはその不変測 度が求められている ${ }^{(35)}$. 一方. SSSでは, $N$ 個のバッファに は常に一定の割合でパーツが供給され, サーバが接続された バッファのみがサーバによって処理される. バッファに供給 されるパーツの総量とサーバの処理量が等しいとおく.サー バのスケジューリングとして, 接続したバッファが空になっ たとき最も多くパーツがたまっているバッファに切り換える という規則を用いる。 $N=3$ のを，SSSのスケジューリン グ則は有限オートマトンで記述でき, システムの振舞いは周 期的になることが示されている(35)，(36).

このように, バッファとサーバの接続の仕方によってシス テムの振舞いが対照的となる。 また, SASにおけるカオス的 な振舞いを周期軌道に安定化するための規則が提案されてい る ${ }^{(37) \sim(39)}$. 


\section{2 内部コネクションを持つSAS}

$N$ バッファからなるSASをまず考える。 $x_{i}(t)$ を時刻 $t \geq 0$ に打けるバッファ $i$ 内のパーツの量と打く. 各バッファ $i て ゙$ は単位時間当り $\lambda_{i}>0$ のパーツが取り除かれる。サーバは単 位時間当り 1 のパーツを供給する。.以下, $\sum_{i=1}^{N} \lambda_{i}=1, \sum_{i=1}^{N}$ $x_{\mathrm{i}}(0)=1$ と仮定する。したがって, 各時刻 $t \geq 0$ で, $\sum_{i=1}^{N} x_{\mathrm{i}}(t)$ $=1$ となる. $T_{n}$ を $n$ 番目の切換が発生したときの時刻とおき, そのとき, サーバが移動するバッファの番号を $l\left(T_{n}\right)$ とおく. ここで，

$$
\tau_{n}=\min _{i \neq l\left(T_{n}\right)}\left\{\frac{x_{i}\left(T_{n}\right)}{\lambda_{i}}\right\}
$$

とおくと, $T_{n+1}=T_{n}+\tau_{n}$ となる. 時刻 $t$ での状態は次式で与 えられる。

$$
x_{i}(t)= \begin{cases}x_{i}\left(T_{n}\right)-\lambda_{i}\left(t-T_{n}\right) & \text { if } i \neq l\left(T_{n}\right) \\ x_{i}\left(T_{n}\right)+\left(1-\lambda_{i}\right)\left(t-T_{n}\right) & \text { if } i=l\left(T_{n}\right)\end{cases}
$$

更に, 状態 $x(t)$ は常に次式の $N$ 次元シンプレックス $X$ の中 にある。

$$
X=\left\{x=\left(x_{1}, \ldots, x_{N}\right): \sum_{k=1}^{N} x_{k}=1, x_{k} \geq 0\right\}
$$

バッファ切換が, $1 \rightarrow 2 \rightarrow \ldots \rightarrow N \rightarrow 1$ となる $N$ 周期軌道が SAS には存在する。このとき, バッファ $i$ にサーバが移動し たときの状態 $x^{(i)}$ は

$$
x^{(i)}=\frac{1}{\triangle}\left(\begin{array}{c}
\left(1-\lambda_{1}-\cdots-\lambda_{i-1}\right) \lambda_{1} \\
\vdots \\
\left(1-\lambda_{i-1}\right) \lambda_{i-1} \\
0 \\
\lambda_{i} \lambda_{i+1} \\
\vdots \\
\left(\lambda_{i}+\cdots+\lambda_{N-1}\right) \lambda_{N}
\end{array}\right)
$$

\section{となる．}

次に, 図 5 に示すような $N-1$ 個の内部コネクションのある SASを考える ${ }^{(40)}$. ただし，コネクション $i$ はバッファ $i$ と $i+$ 1 を結合するコネクションで，パーツの流れる方向は $i$ から $i$ +1方向とする。ここで, $\mu_{i}$ はコネクションiの流速で, 外部 から制御できるものとする。このSASのハイブリッドオート マトンによる表現を図6に示す。ここで，各節点は離散状態 を表し，それぞれはどのバッファにサーバが供給しているか を表しており，その離散状態での連続変数に関する微分方程 式を節点の中に記述している，枝上の数式はその離散遷移が 生起する条件を表し，その条件を満たしたときには必ずその 遷移が生起する。この遷移は「空になったバッファにサーバ は切り換える.」という制御則によるものである。

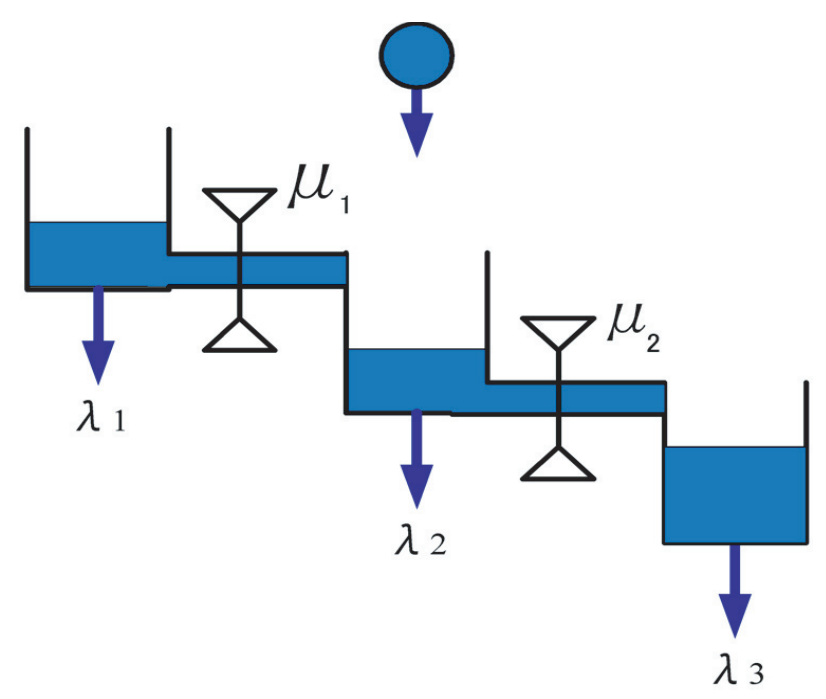

図5 内部コネクションのあるSAS

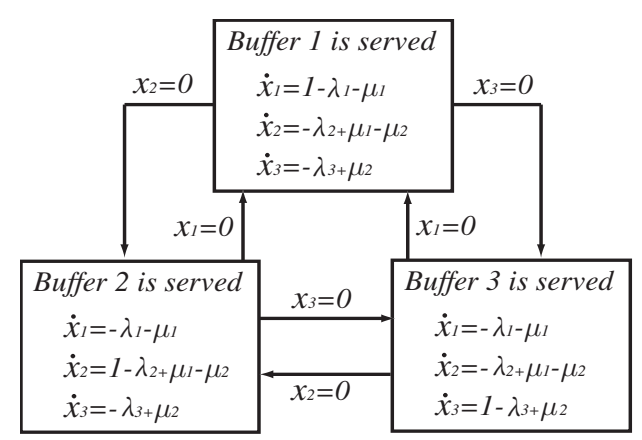

図6 内部コネクションのあるSASのハイブリッドオートマトン モデル

\section{3 カオス制御}

制御法の基本的な考え方を述べるために，N=3の場合を 考える。このとき, 軌道が四7 のようになる。軌道 $a b c$ を安 定化したい 3 周期軌道とする。軌道が辺 $B C=\left\{\left(x_{1}, x_{2}, 0\right)\right.$ : $\left.\sum_{k=1}^{2} x_{k}=1, x_{k}>0\right\}$ 上の点 $x\left(x_{1}, x_{2}, 0\right)$ にあるとする. 辺 $A C=\left\{\left(0, x_{2}, x_{3}\right): \sum_{k=2}^{3} x_{k}=1, x_{k}>0\right\}$ 上の周期点 $a$ に到 着するように内部コネクションの速度 $\mu_{1}$ と $\mu_{2}$ を指定するこ とができれば， 3 周期軌道は安定化される。周期点 $a$ は

$$
a=\left(0, \frac{\lambda_{1} \lambda_{2}}{\lambda_{1} \lambda_{2}+\lambda_{1} \lambda_{3}+\lambda_{2} \lambda_{3}}, \frac{\lambda_{1} \lambda_{3}+\lambda_{2} \lambda_{3}}{\lambda_{1} \lambda_{2}+\lambda_{1} \lambda_{3}+\lambda_{2} \lambda_{3}}\right) .
$$

なので, 今, 点 $x$ から出発した軌道が $a$ に到着したとすると,

$$
\begin{cases}0 & =x_{1}-\left(\lambda_{1}+\mu_{1}\right) t \\ \frac{\lambda_{1} \lambda_{2}}{\lambda_{1} \lambda_{2}+\lambda_{1} \lambda_{3}+\lambda_{2} \lambda_{3}} & =x_{2}-\left(\lambda_{2}-\mu_{1}+\mu_{2}\right) t \\ \frac{\lambda_{1} \lambda_{3}+\lambda_{2} \lambda_{3}}{\lambda_{1} \lambda_{2}+\lambda_{1} \lambda_{3}+\lambda_{2} \lambda_{3}} & =0+\left(1-\lambda_{3}+\mu_{2}\right) t .\end{cases}
$$

が成り立つ。この式から時刻 $t$ を消去すると 


$$
\frac{\frac{\lambda_{1} \lambda_{3}+\lambda_{2} \lambda_{3}}{\lambda_{1} \lambda_{2}+\lambda_{1} \lambda_{3}+\lambda_{2} \lambda_{3}}}{x_{1}}=\frac{1-\lambda_{3}+\mu_{2}}{\lambda_{1}+\mu_{1}} .
$$

となるので，この式を満たすように $\mu_{1}$ と $\mu_{2}$ を定めればよい. ここで $\mu_{2}=0$ と選べば，次式が得られる.

$$
\mu_{1}=-\lambda_{1}+\frac{\lambda_{1} \lambda_{2}+\lambda_{1} \lambda_{3}+\lambda_{2} \lambda_{3}}{\lambda_{3}} x_{1}
$$

このように内部コネクションは一つでカオス制御できること が分かる。

同様にして,$N$ バッファの場合に, 点 $x\left(0, x_{2}, \ldots, x_{N}\right)$ か ら出発した軌道が次の切換のときに周期軌道上にあるように 制御するためには，次のように $\mu_{\mathrm{i}}$ を設定すればよい.

$$
\begin{aligned}
\mu_{1} & =1-\lambda_{1}+\frac{\left(1-\lambda_{1}\right) \lambda_{1} \lambda_{N}}{\left(\lambda_{2}+\cdots+\lambda_{N-1}\right) \lambda_{N}-\Delta x_{N}} \\
\mu_{2} & =\mu_{1}-\lambda_{2}+\frac{-\triangle x_{2} \lambda_{N}}{\left(\lambda_{2}+\cdots+\lambda_{N-1}\right) \lambda_{N}-\Delta x_{N}} \\
\mu_{3} & =\mu_{2}-\lambda_{3}+\frac{\left(\lambda_{2} \lambda_{3}-\triangle x_{3}\right)\left(\lambda_{N}-\mu_{N-1}\right)}{\left(\lambda_{2}+\cdots+\lambda_{N-1}\right) \lambda_{N}-\triangle x_{N}} \\
\ldots & \cdots \cdots \\
\mu_{k} & =\mu_{k-1}-\lambda_{k}+ \\
& \frac{\left(\left(\lambda_{2}+\cdots+\lambda_{k-1}\right) \lambda_{k}-\triangle x_{k}\right) \lambda_{N}}{\left(\lambda_{2}+\cdots+\lambda_{N-1}\right) \lambda_{N}-\triangle x_{N}} \\
\cdots \quad & \cdots \cdots \\
\mu_{N-2} & =\mu_{N-3}-\lambda_{N-2}+ \\
& \frac{\left(\left(\lambda_{2}+\cdots+\lambda_{N-3}\right) \lambda_{N-2}-\triangle x_{N-2}\right) \lambda_{N}}{\left(\lambda_{2}+\cdots+\lambda_{N-1}\right) \lambda_{N}-\triangle x_{N}} \\
\mu_{N-1} & =0
\end{aligned}
$$

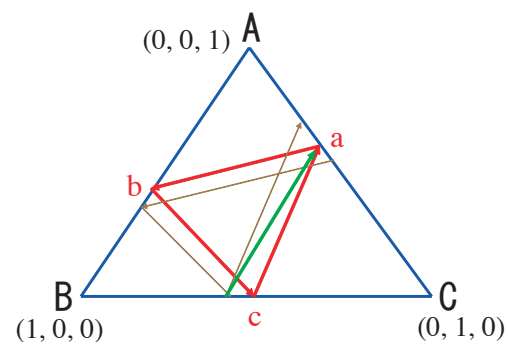

図7 内部コネクションのある 3 バッファのSASの位相平面

ただし,$\Delta x_{i}$ は点 $x$ と目標とする周期点との誤差の $i$ 番目の要 素である，以上より，N-2個の内部コネクションを用いて安 定化できることが分かる。

\section{ハイブリッドレプリケータダイナミック}

\section{1 進化ハイパーゲーム}

レプリケータダイナミックスは, 複数の集団がゲームを繰 り返し行うときの各集団でのプレーヤがとる戦略分布の時間 的変化を表すモデルである。レプリケータダイナミックスは 生態系の進化のモデルとして提案されたが, 今では, 経済学, 人間行動モデル，創発システムなど様々な分野で使われてい
る. 従来のレプリケータダイナミックスでは, 他集団の戦略 を直接認識できると仮定しているが, ハイパゲームでは, こ の仮定を外し, 他集団の戦略を何らかの方針に従って解釈し, 分類するということがしばしば行われる。このような状況は, 各集団の他集団の戦略に対する解釈を表す解釈関数を導入し たモデルで表現できる ${ }^{(41)}$.

多数の主体からなる $n$ 個の集団 $P_{1}, \ldots, P_{n}$ を考える. 集団 $P_{i}$ の純粋戦略集合を $\Phi_{i}=\left\{1, \ldots, m_{i}\right\}$ とし, 各主体は純粋戦 略をとると仮定する。集団 $P_{i}(i \in N=\{1, \ldots, n\})$ における 戦略分布を $P_{i}$ の集団状態といい, その集合を $S_{i}$ とする。 $P_{i}$ に おいて純粋戦略 $k \in \Phi_{i}$ をとる主体の割合を $s_{i}^{k}$ とおき, $P_{i}$ の 集団状態を $s_{i}=\left(\mathrm{s}_{i}{ }^{1}, \ldots, s_{i}{ }^{m i}\right) \in S_{i}$ で表す. 更に， $\Phi_{i j}$ と $S_{i j}$ を それぞれ, $P_{j}$ の主体の認識する $P_{i}$ の純粋戦略, 集団状態の集 合とする. 集団状態の組の集合 $S$ を, 直積 $S=\times_{i \in N} S_{i}$ で定 義する. $s \in S$ から $s_{i}$ を除いたものを $s_{-i}=\left(s_{1}, \ldots, s_{i-1}, s_{i+}\right.$ $\left.{ }_{1}, \ldots, s_{n}\right)$ で表す. $S_{i i}=S_{i}$ として $, R_{i}: \times_{j \in N} S_{j i} \rightarrow \mathbb{R}$ を集団 $P_{i}$ の利得関数とする. 関数 $f_{i j}: S_{i} \rightarrow S_{i j}$ を $P_{j}$ の $P_{i}$ の集団状態に 対する解釈関数と呼ぶ. ここで, $f_{i i}$ は恒等写像 $f_{i i}\left(s_{i}\right)=s_{i}$ である. $f_{i j}$ を用いて, 集団状態の組 $s \in S$ に対する $P_{j}$ の解釈 を $f_{j}(s)=\left(f_{1 j}\left(s_{1}\right), \ldots, f_{n j}\left(s_{n}\right)\right)$ で表す. 以上により, 八イ パゲームにおけるレプリケータダイナミックスは, すべての $i \in N$ と $k \in \Phi_{i}$ に対して以下のように得られる ${ }^{(41)}$.

$$
\dot{s}_{i}^{k}=s_{i}^{k}\left[R_{i}\left(f_{i}\left(e_{m_{i}}^{k}, s_{-i}\right)\right)-R_{i}\left(f_{i}(s)\right)\right]=\xi_{f}^{k}(s) .
$$

ここで $e_{m i}^{k}$ は，第 $k$ 成分が 1 の $m_{i}$ 次元単位列ベクトルである.

\section{2 解釈関数の切換を考慮したモデル}

一般に, 採用する解釈関数が異なれば, 得られる利得も変っ てくる，そこで，利得が最も高く得られる解釈関数に切り換 えるという行為が考えられる。このように集団の状態に応じ て解釈関数を切り換えるとき, そのダイナミックスはハイブ

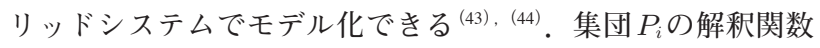
の集合を $\mathcal{F}_{i}=\left\{f_{i}^{1}, \ldots, f_{i}^{m f i}\right\}$ とし, その要素を $f_{i} \in \mathcal{F}_{i}$ で表す. また, 解釈関数の組の集合を $\mathcal{F}=X_{i \in N} \mathcal{F}_{i}$ とし, $f(s)=\left(f_{1}\right.$ $\left.(s), \ldots, f_{n}(s)\right) \in \mathcal{F}$ とする。 $P_{i}$ が解釈関数を $f_{i}^{k}(s)$ から $f_{i}^{k^{\prime}}$ (s) に切り換えることを表す事象を $\sigma_{i}^{k k^{\prime}}$ で定義し, そのような 事象の集合を $\sum$ とする。 $P_{i}$ が解釈関数 $f_{i}^{k}(s)$ を用い, かつ $f_{i}^{k^{\prime}}$ $(s)$ を用いた場合の $P_{i}$ の主体の平均利得と現在の平均利得と の差が $\lambda_{i}^{k k^{\prime}}>0$ 以上であるとき, 事象 $\sigma_{i}^{k k^{\prime}} \in \sum$ が生起すると 定める. 各集団の解釈関数がこの条件によって離散的に, 各 集団の集団状態が式 (19) によって連続的に変化するため, こ のモデルはハイブリッドシステムとなる。したがって, この モデルをハイブリッドオートマトン

$$
R D=\left(\mathcal{F}, S, \mathcal{F}_{\text {init }}, S_{\text {init }}, \Xi, \sum, G\right)
$$

で表すことができる。ここで， $\mathcal{F}_{\text {init }} \times S_{\text {init }} \subseteq \mathcal{F} \times S$ は初期 状態の集合で， $\Xi=\left\{\xi_{f}: S \rightarrow X_{i \in N} \mathbb{R}^{m_{i}}\right\}_{f \in \mathcal{F}}$ は連続状態の 


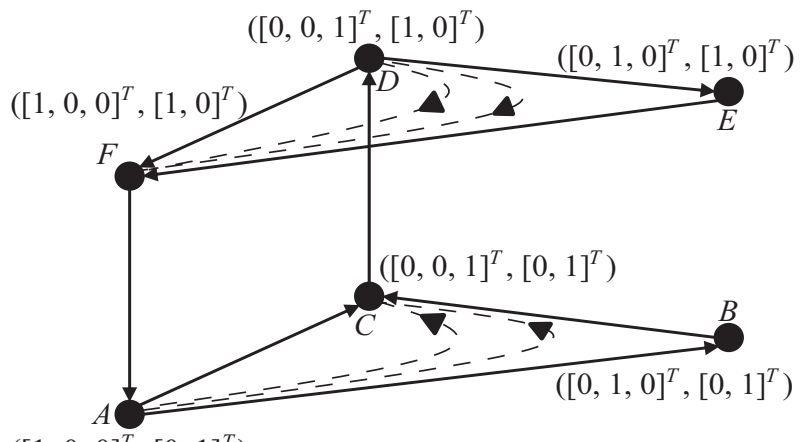

$\left([1,0,0]^{T},[0,1]^{T}\right)$

図8＼cjkstart境界上のヘテロクリニック軌道
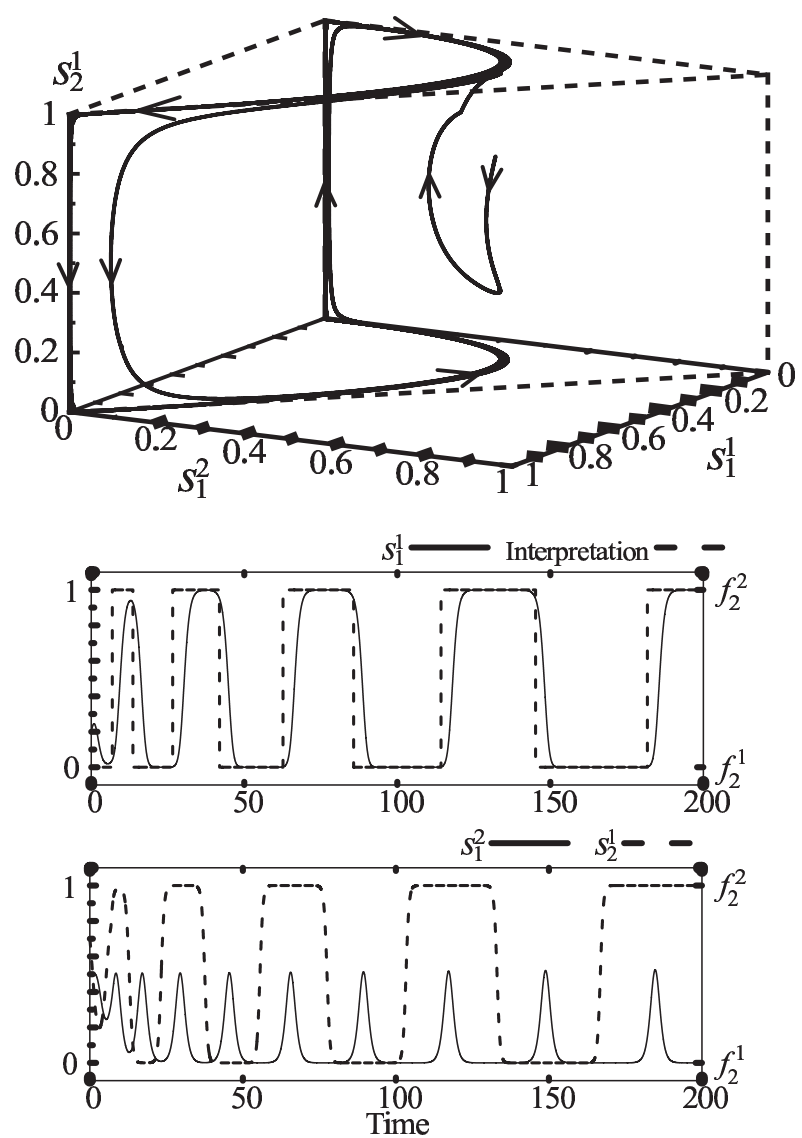

図9 $f_{2}$ の変化を伴った解軌道の例

フローの集合, $G: \sum \rightarrow 2^{S}$ は各事象に対するジャンプ条件を 表す. 各 $f \in \mathcal{F}$ に対してフロー $\xi_{f} \in \Xi は ， \xi_{f i}=\left(\xi_{f i}^{1}, \ldots\right.$, $\left.\xi_{f_{i}}^{m_{i}}\right)$ で, $\xi_{f}=\left(\xi_{f 1}, \ldots, \xi_{f n}\right)$ とし, 式 (19) によって定める. また事象 $\sigma_{\mathrm{i}}^{k k^{\prime}} \in \sum に$ 対して,

$$
G\left(\sigma_{i}^{k k^{\prime}}\right)=\left\{s \in S: R_{i}\left(f_{i}^{k^{\prime}}(s)\right)-R_{i}\left(f_{i}^{k}(s)\right) \geq \lambda_{i}^{k k^{\prime}}\right\}
$$

と定め, $s \in G\left(\sigma_{i}^{k k^{\prime}}\right)$ が成立するとすぐに事象 $\sigma_{i}^{k k^{\prime}}$ が生起す るとする。

\section{3 例題 : サッカーのフーリガニズム}

例として，認識される利得が表1であるサッカーのフーリ ガニズムを考える. 各結果に対して, 一つめの数字がファン
表1 サッカーのフーリガニズムにおける利得

Fans' Game

Authorities' Game

\begin{tabular}{c|c|c|} 
& Tou. & Tol. \\
\hline Beh. & 3,5 & 4,6 \\
\hline P.H. & 2,3 & 5,4 \\
\hline R.H. & 1,2 & 6,1
\end{tabular}

\begin{tabular}{c|c|c|} 
& Int. & Non-Int. \\
\hline Acc. & 1,2 & 3,4 \\
\hline Unacc. & 2,3 & 4,1 \\
\hline
\end{tabular}

の，二つめの数字が当局の認識する利得をそれぞれ表してい る。ファン $\left(P_{1}\right)$ の戦略は上から, 当局 $\left(P_{2}\right)$ の戦略は左から 順に番号をつけ，ファンのゲームの集団状態を $s_{1}$ と $s_{21}$, 当局 のゲームの集団状態を $s_{12}$ と $s_{2}$ でそれぞれ表す。解釈関数の組 として $f^{1}=\left(f_{1}, f_{2}^{1}\right)$ と $f^{2}=\left(f_{1}, f_{2}^{2}\right)$ を考える. ただし $f_{1}(s)$ $=\left(s_{1}, s_{2}\right)$ とし, $f_{2}^{1}(s)=\left(\left[s_{1}^{1}+s_{1}^{2}, s_{1}^{3}\right]^{T}, s_{2}\right), f_{2}^{2}(s)=\left(\left[s_{1}^{1}\right.\right.$, $\left.\left.s_{1}^{2}+s_{1}^{3}\right]^{T}, s_{2}\right)$ とする. $\sum s_{1}^{i}=\sum s_{2}^{i}=1$ に注意すると, 式 (19) より連続時間ダイナミックスは以下のように定式化される.

$$
\begin{aligned}
\dot{s}_{1}^{1} & =s_{1}^{1}\left(1-2 s_{2}^{1}\right)\left(2 s_{1}^{1}+s_{1}^{2}-2\right) \\
\dot{s}_{1}^{2} & =s_{1}^{2}\left(1-2 s_{2}^{1}\right)\left(2 s_{1}^{1}+s_{1}^{2}-1\right) \\
\dot{s}_{2}^{1} & = \begin{cases}2 s_{2}^{1}\left(1-s_{2}^{1}\right)\left(1-2 s_{1}^{1}-2 s_{1}^{2}\right) & \text { for } f_{2}^{1} \\
2 s_{2}^{1}\left(1-s_{2}^{1}\right)\left(1-2 s_{1}^{1}\right) & \text { for } f_{2}^{2}\end{cases}
\end{aligned}
$$

このダイナミックスは, 集団 $P_{2}$ の解釈関数 $f_{2}$ が $f_{2}^{1}$ または $f_{2}^{2}$ に固定されている場合, 漸近安定な平衡点は存在せず， $S$ の 内部のすべての解軌道が非孤立な周期軌道となっている。

本稿では, 集団 $P_{2}$ が解釈関数を $f_{2}^{1}$ から $f_{2}^{2}$ に, 逆に, $f_{2}^{2}$ か ら $f_{2}^{1}$ に相互に変更できるとする. すなわち $\sum=\left\{\sigma_{2}^{12}, \sigma_{2}^{21}\right\}$ とする. 式(21) から, ジャンプ条件は以下の式より得られる.

$$
\begin{aligned}
& R_{2}\left(f_{2}^{2}(s)\right)-R\left(f_{2}^{1}(s)\right)=-s_{1}^{2}\left(3-4 s_{2}^{1}\right) \\
& R_{2}\left(f_{2}^{1}(s)\right)-R\left(f_{2}^{2}(s)\right)=s_{1}^{2}\left(3-4 s_{2}^{1}\right)
\end{aligned}
$$

この場合, $S$ 内部の多くの解軌道では $f_{2}$ の切換が起るため, 非孤立な周期軌道とはならない。解軌道は， $f_{2}$ の変化に伴っ て, $f^{1}$ 上の周期軌道と $f^{2}$ 上の周期軌道を行き来し, $S$ の境界 上にあるへテロクリニック軌道に収束する。このへテロクリ ニック軌道の概略を図8 に示し, 漸近する解軌道の例を図 9 に示す. 四9において, 解軌道がへテロクリニック軌道に収 束する過程で，鞍点に繰り返し近づくたびに，その近くにと どまる時間が長くなるという現象が見られる，またそれと同 時に, $f_{2}$ の切換の間隔も長くなっていることが分かる。この ような現象は, 一般のレプリケータダイナミックスに扎いて, 既に観測されている ${ }^{(42)}$.ここで重要なことは, すべての解軌 道が非孤立な周期軌道であるような，非常にシンプルなダイ ナミックスを切り換えることによって, 罒9のような現象が 生じ得るということである.

\section{7. おわりに}

本稿では，ハイブリッドシステムの一種である区分的に滑 らかなシステムに打ける非線形現象を中心に紹介した。八 ブリッドシステムの研究は計算機科学の分野においても活発 
に研究されており，そこで発達してきた形式的検証法はいわ ゆる可到達問題をアルゴリズミックに解くことに帰着されて いる。このことは平衡点の吸引領域を求める問題とみなすこ ともでき, 非線形システム理論との新しい融合領域となるで あろう ${ }^{(45)}$.

また，本稿では触れなかったが，八イブリッドシステムに おけるフラクタルはニューラルネットワークとも関係する現

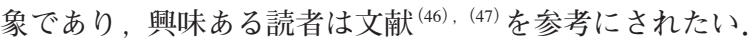

最後に, 本稿の執筆の機会を与えて頂いた非線形問題研究 専門委員会に感謝する。

\section{文献}

(1) A. van der Schaft and H. Schumacher, An Introduction to Hybrid Dynamical Systems, Lect. Notes Control Info. Sci., no. 251, 2000.

（2）引原隆士，“スイッチング回路の非線形ダイナミクスとその解 析,”計測と制御, vol. 44, no. 7, pp. 440-445, 2005.

(3) T. Saito, H. Torikai, and W. Schwarz, "Switched dynamical systems with double periodic inputs: an analysis tool and its application to the buck-boost converter," IEEE Trans. Circuits Syst.,-I, Fundam. Theory. Appl. vol. 47, no. 7, pp. 1038 - 1046, 2000.

(4) H. S. Witsenhausen, "A class of hybrid-state continous-time dynamical systems," IEEE Trans. Autom. Control, vol. AC-11, no. 2, pp. 161-167, 1966

(5) Z. T. Zhusubaliyev and E. Mosekilde,Bifurcations and Chaos in Piecewise-Smooth Dynamical Systems, World Scientific, 2003.

(6) H. Matsuno, C. Li, and S. Miyano, "Petri net based descriptions for systematic understanding of biological pathways," IEICE Trans. Fundamentals, vol. E89-A, no. 11, Nov. pp. 3166-3174, 2006.

(7) H. Nakayama, H. Tanaka, and T. Ushio, "The formulation of the control of an expression pattern in a gene network by propositional calculus," J. Theoretical Biology, vol. 240, no. 3, pp. 443-450, 2006.

(8) N. Takahashi, S. Doi, and S. Kumagai, "Switching dynamics, chaos, and singular perturbation analysis of heart arrhythmia," Proc. NOLTA2006, pp. 71-74, 2006.

(9) Y. Kon'no, T. Saito, and H. Torikai, "Rich dynamic of pulse-coupled spiking neurons with a triangular base signal," Neural Networks, vol. 18, pp. 523-531, 2005.

(10) J. Laugesen and E. Mosekilde, "Border-collision bifurcation in a dynamic management game”, Comput. Oper. Res., vol. 33, no. 2, pp. 464-478, 2006.

（11）潮俊光, “ハイブリッドシステムへの誘い,”計測と制御, vol. 44, no. 7, pp. 429-433, 2005.

(12) T. A. Henzinger, "The theory of hybrid automata," Proc. 11th Symp. Logic in Comp. Sci., pp. 278-292, 1996.

(13) R. Alur, T. A. Henzinger, G. Lafferriere, and G. J. Pappas, "Discrete abstraction of hybrid systems," Proc. IEEE, vol. 88, no. 7, pp. 971984, 2000

(14) A. F. Filippov, Differential Equation with Discontinuous RightHand Side, Kluwer Academic, 1988.

(15) R. I. Leine and H. Nijmeijer, Dynamics and Bifurcations of NonSmooth Mechanical Systems, Springer, 2004.

(16) R. I. Leine and D. H. van Campen, "Bifurcation phenomena in nonsmooth dynamical systems,” Eur. J. Mech. A, Solids, vol. 25, no. 4, pp. 595-616, 2006.

（17）野波健蔵，田宏奇，スライディングモード制御，コロナ社, 1994.

(18) P. Kowalczyk and M. di Bernardo, "Two-parameter degenerate sliding bifurcation in Filippov systems," Physica D, vol. 204, no. 1, pp. 204-229, 2005.

(19) M. di Bernardo, N. I. Feigin, S. J. Hogan, and M. E. Homer, "Local analysis of $C$-bifurcation in $n$-dimensional piecewise-smooth dynamical systems," Chaos Solitions Fractals, vol. 10, no. 11, pp. 1881-1908, 1999.

(20) M. Feigin, "Doubling of the oscillation period with $C$-bifurcations in piecewise continuous systems," J. Appl. Math. Mech., vol. 34, no. 5, pp. 822-830, 1970
(21) M. Feigin, "On the structure of $C$-bifurcation boundaries of piecewise continuous systems,” J. Appl. Math. Mech., vol. 42, no. 5, pp. $820-829,1978$

(22) M. Feigin, "The increasingly complex structure of the bifurcation tree of a piecewise-smooth system," J. Appl. Math. Mech., vol. 59, no. 6, pp. 853-863, 1995.

(23) H. E. Nusse and J. A. Yorke, "Border-collision bifurcation including "period two to period three' for piecewise smooth systems," Physica D, vol. 57, no. 1, pp. 39-57, 1992.

(24) H. E. Nusse, E. Ott, and J. A. Yorke, "Border-collision bifurcation: an explanation for observed bifurcation phenomena," Phys. Rev. E, vol. 49, no. 2, pp. 1073-1076, 1994.

(25) A. B. Nordmark, "Non-periodic motion caused by grazing incidence in an impact oscillator," J. Sound Vib., vol. 145, no. 2, pp. 279-297, 1991

(26) A. B. Nordmark, "Universal limit mapping in grazing bifurcations," Phys. Rev. E, vol. 55, no. 1, pp. 266-270, 1997.

(27) M. di Bernardo, C. J. Budd, and A. R. Champneys, "Grazing and border-collision in piecewise-smooth systems: a unified analytical framework," Phy. Rev. Lett., vol. 86, no. 12, pp. 2553-2556, 2001.

(28) V. Donde and I. Hisken, "Shooting for border collision bifurcations in hybrid systems," Proc. 42nd IEEE CDC, pp. 5514-5519, 2003.

(29) V. Donde and I. Hisken, "Grazing bifurcations in periodic hybrid systems,” Proc. ISCAS2004, pp. IV-697-IV-700, 2004.

(30) Y. Ma, S. Banerjee, T. Kousaka, and T. Ueta, "Classification and analytical method of switched dynamical systems," Proc. NOLTA2006, pp. 63-66, 2006.

(31) G. Yuan, S. Banerjee, E. Ott, and J. A. Yorke, "Border-collision bifurcations in the Buck Converter," IEEE Trans. Circuits Syst.,-I, Fundam. Theory Appl. vol. 45, no. 7, pp. 707-716, 1998.

(32) M. A. Hassouneh, E. H. Abed, and H. Nusse, "Robust dangerous border-collision bifurcations in piecewise smooth systems," Phys. Rev. Lett., vol. 92, no. 7, 070201, 2004.

(33) A. Ganguli and S. Banerjee, "Dangerous bifurcation at border collision: when does it occur?," Phys. Rev. E, vol. 71, no. 5, $057202,2005$.

(34) A. B. Nordmark and P. Kowalczyk, "A codimension-two scenario of sliding solution in graizing-sliding bifurcations," Nonlinearity, vol. 19, no. 1, pp. 1-26, 2006.

(35) C. Chase, J. Serrano, and P. J. Ramadge, "Periodicity and chaos from switched flow systems: contrasting examples of discretely controlled continuous systems," IEEE Trans. Autom. Control, vol. 38, no. 1, pp. 70-83, 1993.

(36) A. S. Matveev and A. V. Savkin, Qualitative Theory of Hybrid Dynamical Systems,Birkhäuser, 2000.

(37) T. Ushio, H. Ueda, and K. Hirai, "Controlling chaos in a switched arrival system,” Syst. Control Lett., vol. 26, no. 5, pp. 335-339, 1995.

(38） 潮俊光, 上田秀樹, 平井一正, “ $N$ バッファスイッチトアライ バルシステムにおけるカオス制御,”信学論 $(\mathrm{A})$, vol. J81-A, no. 12, pp. 1758-1763, Dec. 1998.

(39) Y. P. Tian, X. H. Yu, and L. O. Chua, "Time-delayed impulsive control of chaotic hybrid systems," Int. J. Bifurcation and Chaos, vol. 14, no. 3, pp. 1091-1104, 2004.

(40) W. Li and T. Ushio, "Control of a chaotic switched arrival system with controlled internal connections," Int. J. Bifurcation Chaos, vol. 16, no. 3, pp. 701-708, 2006.

(41) T. Kanazawa, T. Ushio, and T. Yamasaki, "Replicator dynamics of evolutionary hypergames," IEEE Trans. Syst., Man, Cybern. A, Syst. Humans vol. 37, no. 1, pp. 132-138, 2007.

(42) T. Chawanya, "A new type of irregular motion in a class of game dynamics systems," Prog. of Theor. Phys., vol. 94, no. 2, pp. 163$179,1995$.

(43) T. Kanazawa and T. Ushio, "Multi-population replicator dynamics with changes of interpretations of strategies," IEICE Trans. Fundamentals, vol. E89-A, no. 10, pp. 2717-2723, Oct. 2006.

(44) T. Kanazawa and T. Ushio, "Nonlinear phenomena in hybrid replicator dynamics with changes of interpretation functions," Proc. NOLTA2006, pp. 167-170, 2006.

(45) Y. Susuki, T. Hikihara, and H. Ebina, "Predicting instability of power systems based on hybrid system reachability analysis," Proc. 
NOLTA2006, pp. 75-78, 2006

(46) 郷原一寿, “常微分方程式の確率的切り替えとフラクタル,”計 測と制御, vo. 44, no. 7, pp. 434-439, 2005.

(47) K. Gohara, "Fractals in hybrid systems," Proc. NOLTA2006, pp 171-174, 2006.

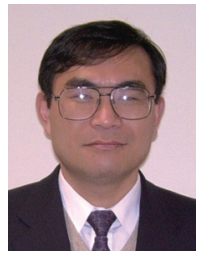

潮 俊光 (正員)

昭 55 神戸大・工・システム卒. 昭 60 同大学院博士 課程了．同年カリフォルニア大研究員. 昭 61 神戸大 助手. 平 9 阪大大学院基礎工学研究科教授となり, 現 在に至る。離散事象システムのスーパバイザ制御，リ アルタイムシステムの適応的資源配分制御, 非線形シ ステムのカオス制御・カオス同期などの研究に従事. 学術博士. 平 18 年度論文賞受賞.

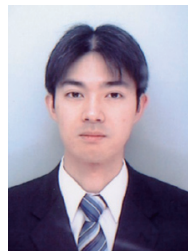

金澤 尚史 (正員)

平 15 阪大 · 基礎工 ・ システム卒. 平 19 同大学院シ ステム創成専攻博士課程了.

同年阪大大学院基礎工学研究科助教となり, 現在に至る. 進化ゲーム理論やハイパゲーム理論に関する研究に従 事. 博士 (工学). 